\title{
PSYCHE
}

VOL. XXXIX

DECEMBER, 1932

No. 4

\section{THE ENTOMOLOGICAL PUBLICATIONS OF C. W. JOHNSON}

\author{
By A. L. Melander
}

College of the City of New York, New York, N. Y.

In presenting the following list of the entomological writings of the late Charles Willison Johnson, I sincerely hope that no important titles have been omitted. This list has been checked with the libraries of J. M. Aldrich, C. T. Brues and myself, the Zoological Record, Biological Abstracts and several bibliographical references. Finally $\mathrm{Mr}$. Richard Dow has compared it with the collection of reprints in the Boston Society of Natural History, verified the dates of publication and added many missing titles.

In addition to the cited titles, Mr. Johnson issued numerous brief notices in the Bulletins of the Boston Society of Natural History. Only the more important of these are included, but an Index to Bulletins 1-50 was issued in October, 1931.

A biographical account of Mr. Johnson has been given by W. Sprague Brooks in Bulletin 65 of the Boston Society of Natural History, October, 1932.

As a fellow dipterist I wish to record my sorrow in the passing of Johnson and my appreciation of having shared his friendship. In the formative days of my career his 
generosity in furnishing determined specimens gave that stimulus helpful to the beginner. A few days ago I had occasion to study some specimens of the Johnson collection now located at the Harvard museum. The methodical arrangement of his insects, his neatly written labels and the suggestions of many collecting trips given by the locality labels make it hard to comprehend that this collection has been completed and that the mind and the hand of the curator are forever stilled.

\section{3}

Puparium of Ceria signifera. Ent. News, vol. 4, p. 91 (1893).

\section{4}

List of the Diptera of Jamaica with descriptions of new species. Proc. Acad. Nat. Sci. Philadelphia for 1894, pp. 271-281 (1894).

\section{5}

Diptera of Florida. With additional descriptions of new genera and species by D. W. Coquillett. Proc. Acad. Nat. Sci. Philadelphia for 1895, pp. 303-340 (1895).

A review of the Stratiomyia and Odontomyia of North America. Trans. American Ent. Soc., vol. 22, pp. 227-278, pls. 3-4. (1895).

\section{7}

[A few notes on the distribution of Platypeza.] Ent. News, vol. 8, p. 254 (1897).

Some notes and descriptions of new Leptidæ. Ent. News, vol. 8, pp. 117-120 (1897).

\section{8}

Notes and descriptions of new Syrphidæ from Mt. St. Elias, Alaska. Ent. News, vol. 9, pp. 17-18 (1898) [Mailed Dec. 1897].

Diptera collected by Dr. A. Donaldson Smith in Somaliland, eastern Africa. Proc. Acad. Nat. Sci. Philadelphia for 1898, pp. 157-164 (1898).

\section{0}

Order Diptera. In Insects of New Jersey by J. B. Smith and others, Suppl. to 27th Annual Report State Board Agric., pp. 617-699 (1900). 
Some notes and descriptions of seven new species and one new genus of Diptera. Ent. News, vol. 11, pp. 323-328 (1900).

New North American Ortalidæ. Canadian Ent., vol. 32, pp. 246-247 (1900).

\section{1}

Variation in the venation of Amalopis inconstans Osten Sacken. Ent. News, vol. 12, pp. 305-307 (1901).

\section{2}

On the validity of Dasyllis affinis Macquart. Ent. News, vol. 13, pp. 77-78 (1902).

Remarks on Tephronota ruficeps and description of a new species. Ent. News, vol. 13, pp. 143-144 (1902).

New North American Diptera. Canadian Ent., vol. 34, pp. 240-242 (1902).

\section{3}

A new genus and four new species of Asilidæ. Psyche, vol. 10, pp. 111-114 (1903).

Some notes and descriptions of three new Leptidæ. Ent. News, vol. 14, pp. 22-26 (1903).

Two new species of the family Pipunculidæ. Ent. News, vol. 14, pp. 107-108 (1903).

[with D. W. Coquillett] Diptera of Beulah, New Mexico. Trans. American Ent. Soc., vol. 29, pp. 101-106 (1903).

Descriptions of three new Diptera of the genus Phthiria. Psyche, vol. 10, pp. 184-185 (1903) [Mailed Jan. 1904].

\section{4}

Some notes, and descriptions of four new Diptera. Psyche, vol. 11, pp. 15-20 (1904).

When to collect Tabanidæ. Psyche, vol. 11, p. 35 (1904).

Some of the Diptera to be collected during April and May. Psyche, vol. 11, pp. 37-38 (1904).

Merope tuber. Psyche, vol. 11, p. 38 (1904).

Pelecinus polyturator Drury. Psyche, vol. 11, p. 38 (1904).

A revised list of the Diptera of Bermuda. Psyche, vol. 11, pp. 76-80 (1904).

A supplementary list of the Diptera of New Jersey. Ent. News, vol. 15, pp. 157-163 (1904). 


\section{5}

[Review of Mosquitos or Culicidæ of New York State by E. P. Felt.] Psyche, vol. 12, p. 26 (1905).

[Review of Report of the New Jersey State Agricultural Experiment Station upon the mosquitoes occurring within the state, their habits, life history, etc. by J. B. Smith.] Psyche, vol. 12, p. 50 (1905).

Synopsis of the tipulid genus Bittacomorpha. Psyche, vol. 12 , pp. 75-76 (1905).

[Review of $A$ catalogue of North American Diptera by J. M. Aldrich.] Psyche, vol. 12, pp. 77-78 (1905).

[Review of May flies and midges of New York by J. G. Needham, K. J. Morton, and O. A. Johannsen.] Psyche, vol. 12, p. 106 (1905).

[Review of Wasps social and solitary by G. W. and E. G. Peckham.] American Naturalist, vol. 39, pp. 602-603 (1905).

\section{6}

Notes on some dipterous larvæ. Psyche, vol. 13, pp. 1-4, pl. 1 (1906).

Descriptions of two new Diptera of the family Dolichopodidæ. Psyche, vol. 13, pp. 59-60 (1906).

The distribution of the Periodical Cicada in New England in 1906. Psyche, vol. 13, p. 159 (1906).

Charles Robert v. d. Osten Sacken. Ent. News, vol. 17, pp. 273-275 (1906).

[Review of American insects by V. L. Kellogg.] American Naturalist, vol. 40, pp. 137-138 (1906).

\section{7}

A new genus and species of the family Tachinidæ, parasitic on Archips cerasivorana. Psyche, vol. 14, pp. 9-10 (1907).

The Snow-fly, Chionea valga Harris. Psyche, vol. 14, pp. 41-43 (1907).

Some North American Syrphidæ. Psyche, vol. 14, pp. 75-80 (1907).

A review of the species of the genus Bombylius of the eastern United States. Psyche, vol. 14, pp. 95-100 (1907).

[Review of Notes on Jamaican Hemiptera by E. P. Van Duzee.] Psyche, vol. 14, p. 123 (1907) [Mailed Jan. 1908]. 
1908

[Review of Mosquito life by E. G. Mitchell.] Psyche, vol. 15, p. 3 (1908).

Notes on New England Bombyliidæ, with a description of a new species of Anthrax. Psyche, vol. 15, pp. 14-15 (1908).

A note on the distribution of Bittacomorpha jonesi. Psyche, vol. 15, p. 25 (1908).

A note on Calotarsa, and descriptions of two new species of Callimyia. Psyche, vol. 15, pp. 58-59 (1908).

The Screw Worm (Chrysomyia macellaria). Psyche, vol. 15, p. 60 (1908).

The Diptera of the Bahamas, with notes and description of one new species. Psyche, vol. 15, pp. 69-80 (1908).

The distribution of Blepharocera tenuipes Walker. Psyche, vol. 15, p. 104 (1908).

\section{9}

The importance of local ecological studies in entomology. Psyche, vol. 16, pp. 5-12 (1909).

Notes on the synonymy of the species of Erax of the eastern United States. Psyche, vol. 16, pp. 32-33 (1909).

Notes on the distribution of some Trypetidæ with description of a new species. Psyche, vol. 16, pp. 113-114 (1909).

The rediscovery of Glutops singularis Burgess. Psyche, vol. 16, p. 132 (1909).

New and little known Tipulidæ. Proc. Boston Soc. Nat. Hist., vol. 34, pp. 115-133, pls. 15-16 (1909).

The insects, excluding the beetles. In Labrador, the country and the people by W. T. Grenfell and others. New York, Macmillan Co., pp. 427-441, 2 pls. (1909).

\section{0}

A revision of the species of Agathomyia of the eastern United States. Psyche, vol. 17, pp. 7-8 (1910).

A note on the species of Fucellia of eastern North America. Psyche, vol. 17, pp. 76-78 (1910).

Order Diptera. In A report of the insects of New Jersey by J. B. Smith and others, Annual Report New Jersey State Museum 1909, pp. 703-814 (1910). 
Some additions to the dipteran fauna of New England. Psyche, vol. 17, pp. 228-235 (1910) [Mailed Jan. 1911].

\section{1}

Notes on the dipterous genera proposed by Billberg in his Enumeratio insectorum. Psyche, vol. 18, pp. 73-74 (1911).

1912

New North American Diptera. Psyche, vol. 19, pp. 1-5 (1912).

Dipterological notes. Psyche, vol. 19, pp. 102-104 (1912).

The velutinous species of the genus Chrysopilus. Psyche, vol. 19, pp. 108-109 (1912).

New and interesting Diptera. Psyche, vol. 19, pp. 151-153 (1912).

The North American species of the genus Hæmatopota. Psyche, vol. 19, pp. 181-183 (1912) [Mailed Jan. 1913].

1913

Species of the genus Gaurax of the eastern United States. Psyche, vol. 20, pp. 34-35 (1913).

A study of the Clusiodidæ (Heteroneuridæ) of the eastern United States. Psyche, vol. 20, pp. 97-101 (1913).

Notes on variation in the venation of the species of the genus Leptogaster. Psyche, vol. 20, pp. 162-164 (1913).

Merope tuber in Massachusetts. Psyche, vol. 20, p. 170 (1913).

Mantispa interrupta Say in New England. Psyche, vol. 20, p. 170 (1913).

On the Criorhina intersistens Walker and an allied species. Ent. News, vol. 24, pp. 293-295 (1913).

The North American species of the genera Arthropeas and Arthroceras. Canadian Ent., vol. 45, pp. 9-12 (1913).

Insects of Florida. 1. Diptera. Bull. American Mus. Nat. Hist., vol. 32, pp. 37-90 (1913).

The dipteran fauna of Bermuda. Ann. Ent. Soc. America, vol. 6, pp. 443-452 (1913).

The distribution of some species of Drosophila. Psyche, vol. 20, pp. 202-205 (1913) [Mailed Jan. 1914]. 
1914

Some new and interesting species of Sapromyza. Psyche, vol. 21, pp. 20-23 and 82, pl. 3 (1914).

Anasa repetita Heidemann in Massachusetts. Psyche, vol. 21, p. 82 (1914).

The discovery of Eclimus harrisi in the White Mountains, N. H. Psyche, vol. 21, p. 123 (1914).

A new stratiomyid. Psyche, vol. 21, pp. 158-159 (1914).

Notes on inadequate locality labels. Ent. News, vol. 25, pp. 123-126 (1914).

\section{5}

Two new species of Borboridæ. Psyche, vol. 22, pp. 21-22 (1915).

A new species of Pseudotephritis. Psyche, vol. 22, p. 49 (1915).

A fly preserved in paper. Psyche, vol. 22, p. 63 (1915).

A new species of the genus Nephrocerus. Canadian Ent., vol. 47, pp. 54-56 (1915).

The Collection of New England Insects. Bull. Boston Soc. Nat. Hist., no. 3, pp. 3-6 (1915).

Note on the species of the genus Acrocera. Psyche, vol. 22, pp. 198-203 (1915) [Mailed Jan. 1916].

1916

Further studies on the Platypezidæ. Psyche, vol. 23, pp. 27-33 (1916).

Some New England Syrphidæ. Psyche, vol. 23, pp. 75-80 (1916).

Parasites of Archips cerasivorana Fitch. Psyche, vol. 23, p. 81 (1916).

The Volucella bombylans group in America. Psyche, vol. 23, pp. 159-163 (1916) [Mailed Jan. 1917].

1917

A new maritime anthomyid. Canadian Ent., vol. 49, p. 148 (1917).

A new species of Criorhina from New England. Psyche, vol. 24, pp. 153-154 (1917).

Species of the genus Brachyopa of the eastern United States. Canadian Ent., vol. 49, pp. 360-362 (1917). 


\section{8}

Notes on the species of the genus Dioctria. Psyche, vol. 25, pp. 102-103 (1918).

Collecting in a museum. Bull. Boston Soc. Nat. Hist., no. 15, pp. 3-5 (1918).

A glance at the insects of Mt. Washington and Mount Desert. Sieur de Monts Publ., no. 18, pp. 22-25 (1918?).

\section{9}

New species of the genus Villa (Anthrax). Psyche, vol. 26, pp. 11-13 (1919).

The North American Diptera described by Nils S. Swederus. Canadian Ent., vol. 51, p. 32 (1919).

A revised list of the Diptera of Jamaica. Phoridæ by Charles T. Brues. Bull. American Mus. Nat. Hist., vol. 41, pp. 421-449 (1919).

Our insect friends. Bull. Boston Soc. Nat. Hist., no. 19, pp. 3-6 (1919).

On the variation of Tabanus atratus Fabricius. Psyche, vol. 26, pp. 163-165 (1919) [Mailed Jan. 1920].

A new species of the genus Ulidia. Psyche, vol. 26, pp. 165-166 (1919) [Mailed Jan. 1920].

\section{0}

A revision of the species of the genus Loxocera, with a description of a new allied genus and a new species. Psyche, vol. 27, pp. 15-19 (1920).

Descriptions of some new tropical Pachygastrinæ. Psyche, vol. 27, pp. 112-115 (1920).

Variation of the Palm Weevil. Journ. of Heredity, vol. 11, pp. 84-85 (1920). Reprinted in The Guide to Nature, vol. 13, pp. 183-184 (1921).

The female of Glutops singularis Burgess. Psyche, vol. 27, pp. 153-154 (1920) [Mailed Feb. 1921].

\section{1}

A new ptinid for New England. Psyche, vol. 28, p. 7 (1921).

Okanagana rimosa (Say) in Nova Scotia. Psyche, vol. 28 , p. 15 (1921).

A review of the American species of the genus Palloptera. Psyche, vol. 28, pp. 20-23 (1921). 
New Diptera from Texas and Mexico. Psyche, vol. 28, pp. 56-59 (1921).

New species of Diptera. Occ. Papers Boston Soc. Nat. Hist., vol. 5, pp. 11-17 (1921).

\section{2}

Notes on distribution and habits of some of the bird-flies, Hippoboscidæ. Psyche, vol. 29, pp. 79-85 (1922).

New genera and species of Diptera. Occ. Papers Boston Soc. Nat. Hist., vol. 5, pp. 21-26 (1922).

Muscina pascuorum Meigen in New England. Science, n. s. vol. 56, p. 604 (1922).

\section{3}

The occurrence of Muscina pascuorum Meigen in North America in 1922. Psyche, vol. 30, pp. 1-5 (1923).

New species of North American Cyrtidæ. Psyche, vol. 30, pp. 49-51 (1923).

A review of the Platypezidæ of eastern North America. Occ. Papers Boston Soc. Nat. Hist., vol. 5, pp. 51-58, pl. 5 (1923).

New and interesting species of Diptera. Occ. Papers Boston Soc. Nat. Hist., vol. 5, pp. 69-72 (1923).

Collecting Diptera in Maine. The Maine Naturalist, vol. 3, pp. 7-10 (1923).

The Society's insect collection. Bull. Boston Soc. Nat. Hist., no. 31, pp. 3-4 (1923).

The Periodical Cicada. Bull. Boston Soc. Nat. Hist., no. 31, p. 4 (1923).

Notes on the nests of Odynerus (Ancistrocerus) birenimaculatus Saussure. Psyche, vol. 30, pp. 226-227 (1923) [Mailed Jan. 1924].

\section{4}

Notes on Muscina pascuorum Meigen during 1923. Psyche, vol. 31, pp. 17-18 (1924).

A review of the New England species of Chrysotoxum. Occ. Papers Boston Soc. Nat. Hist., vol. 5, pp. 97-100 (1924).

Diptera of the Williams Galapagos Expedition. Zoologica (New York Zool. Soc.), vol. 5, pp. 85-92 (1924). 


\section{5}

A new species of the genus Gaurax. Psyche, vol. 32, p. 47 (1925).

The North American varieties of Volucella bombylans Linn. Psyche, vol. 32, pp. 114-117 (1925).

New species of Diptera from North Carolina and Florida. Psyche, vol. 32, pp. 299-302 (1925).

Diptera of the Harris Collection. Proc. Boston Soc. Nat. Hist., vol. 38, pp. 57-99 (1925).

Fauna of New England. 15. List of the Diptera or twowinged flies. Occ. Papers Boston Soc. Nat. Hist., vol. 7, no. 15, pp. 1-326 (1925).

Insects that infest birds. Bull. Northeastern Bird-banding Assoc., vol. 1, pp. 51 [bis]-53 (1925).

Mantispa interrupta and $M$. brunnea in New England. Psyche, vol. 32, p. 318 (1925) [Mailed Jan. 1926].

[Note on Aellopos titans Cram.] Psyche, vol. 32, p. 318 (1925) [Mailed Jan. 1926].

\section{6}

The distribution of Muscina pascuorum Meigen in America. Psyche, vol. 33, pp. 20-21 (1926).

The synonymy of Actina viridis (Say). Psyche, vol. 33, pp. 88-90 (1926).

A note on Beris annulifera (Bigot). Psyche, vol. 33, pp. 108-109 (1926).

A revision of some of the North American species of Mydaidæ. Proc. Boston Soc. Nat. Hist., vol. 38, pp. 131145, pl. 3 (1926).

[with others] Concerning Townsend's Inside history of North American myiology. Journ. New York Ent. Soc., vol. 34, pp. 69-70 (1926).

\section{7}

Dipterological notes. Psyche, vol. 34, pp. 33-35 (1927).

New species of Scatophagidæ. Psyche, vol. 34, pp. 100103 (1927).

Notes on the present distribution of two introduced moths. Psyche, vol. 34, pp. 176-177 (1927).

Some remarks on questionable types. Proc. Ent. Soc. Washington, vol. 29, pp. 45-46 (1927). 
The infestation of Bluebirds' nests by Protocalliphora. Bull. Northeastern Bird-banding Assoc., vol. 3, pp. 1-3 (1927).

Further studies of Protocalliphora infesting nestling birds. Bull. Northeastern Bird-banding Assoc., vol. 3, pp. 77-82 (1927).

Biological survey of the Mount Desert Region. Part 1. The insect fauna with reference to the flora and other biological features. $248 \mathrm{pp}$. Philadelphia, Wistar Institute of Anatomy and Biology (1927).

[Review of The natural history of ants by R. A. F. de Réaumur, translated and annotated by W. M. Wheeler.] Bull. Boston Soc. Nat. Hist., no. 42, pp. 10-11 (1927).

The Clark Collection of Lepidoptera. Bull. Boston Soc. Nat. Hist., no. 45, pp. 5-6 (1927). Reprinted in Ent. News, vol. 39, pp. 23-24 (1928).

[with others] Report of Committee on National $\mathrm{Mu}-$ seum. Ann. Ent. Soc. America, vol. 20, pp. 140-148 (1927).

The Tricyphona inconstans on Nantucket Island, Mass. Psyche, vol. 34, pp. 216-217 (1927) [Mailed Jan. 1928].

\section{8}

The Periodical Cicada in New England. Bull. Boston Soc. Nat. Hist., no. 47, pp. 3-6 (1928).

The New England Siricidæ or horntails. Bull. Boston Soc. Nat. Hist., no. 49, pp. 3-7 (1928).

Some common insects of the household. (Natural history by radio.) Scientific Monthly, vol. 27, pp. 343-346 (1928).

A new cecidomyiid of the genus Lestodiplosis. Psyche, vol. 35, p. 216 (1928) [Mailed Feb. 1929].

\section{9}

A flight of Pieris monuste. Psyche, vol. 36, p. 92 (1929). Diptera destroying snails. Psyche, vol. 36, p. 106 (1929). A new species of Blepharocera from Massachusetts. Psyche, vol. 36, pp. 123-124 (1929).

Diptera of Labrador. Psyche, vol. 36, pp. 129-146 (1929). 
A note on Chilosia hiawatha Shannon. Psyche, vol. 36, pp. 237-238 (1929).

The injury to nestling birds by the larvæ of Protocalliphora. Ann. Ent. Soc. America, vol. 22, pp. 131-135 (1929).

Some additional notes on Protocalliphora. Bull. Northeastern Bird-banding Assoc., vol. 5, pp. 29-30 (1929).

Some notes on certain of the hippoboscid flies. Bull. Northeastern Bird-banding Assoc., vol. 5, pp. 49-52 (1929).

Nantucket as a collecting ground. Bull. Boston Soc. Nat. Hist., no. 50, pp. 3-6 (1929).

Notes on parasitic Hymenoptera. Bull. Boston Soc. Nat. Hist., no. 51, pp. 8-9 (1929).

Notes on the Syrphidæ collected at Jaffrey and Mount Monadnock, N. H., with a description of a new species. Psyche, vol. 36, pp. 370-375 (1929) [Mailed Jan. 1930].

\section{0}

On the variation and abundance of Sirex nitidus Harris. Psyche, vol. 37, pp. 281-282 (1930).

A bot fly of the White-footed Mouse. Psyche, vol. 37, pp. 283-284 (1930).

The walking-stick, Monomera blatchleyi race atlantica Davis in eastern Massachusetts. Psyche, vol. 37, p. 285 (1930).

Louis William Swett [obituary]. Psyche, vol. 37, pp. 300-301 (1930).

Some notes on mosquitoes. Bull. Boston Soc. Nat. Hist., no. 55, pp. 16-20 (1930).

Notes on Protocalliphora during the summer of 1930. Bird-banding, vol. 1, pp. 169-173 (1930).

A list of the insect fauna of Nantucket, Massachusetts. With a list of the spiders by James H. Emerton. Publ. of the Nantucket Maria Mitchell Assoc., vol. 3, no. 2, pp. 1-176, i-xviii (1930).

\section{1}

Two new species of fungus gnats of the genus Apemon. Psyche, vol. 38, pp. 22-24 (1931).

An interesting copy of Wiedemann's Diptera exotica. Psyche, vol. 38, pp. 25-26 (1931). 
James Henry Emerton [obituary]. Bull. Boston Soc. Nat. Hist., no. 58, pp. 21-22 (1931).

Nestling birds destroyed by the larvæ of Protocalliphora. Bull. Boston Soc. Nat. Hist., no. 59, pp. 21-24 (1931).

[Review of Thomas Say, early American naturalist by H. B. Weiss and G. M. Ziegler.] Bull. Boston Soc. Nat. Hist., no. 60 , pp. 23-24 (1931).

\section{2}

Notes on Protocalliphora during the summer of 1931. Bird-banding, vol. 3, pp. 26-29 (1932).

Reginald Heber Howe [obituary]. Bull. Boston Soc. Nat. Hist., no. 63, pp. 29-30 (1932).

A new species of the genus Mydas. Psyche, vol. 39, p. 72 (1932). 

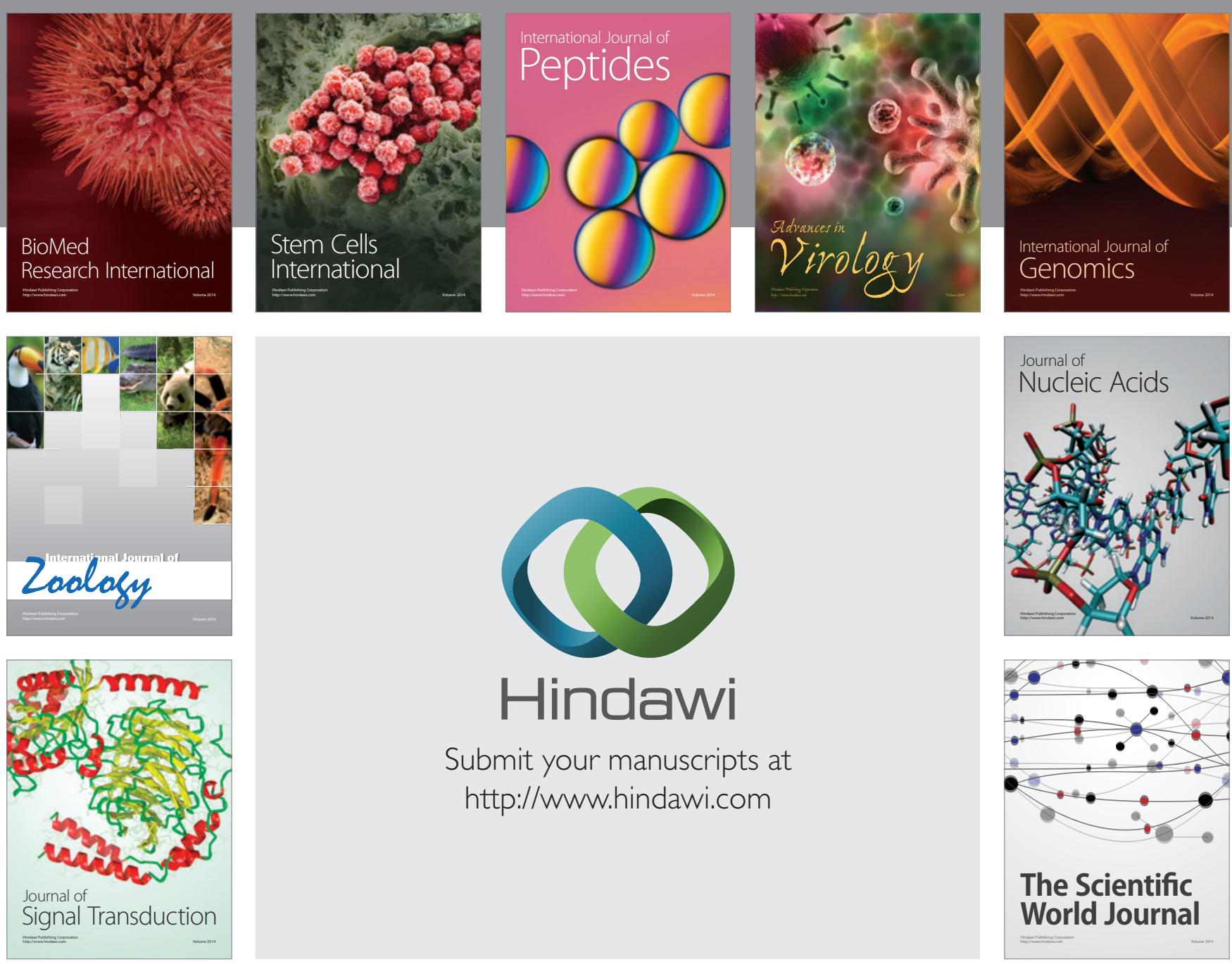

Submit your manuscripts at

http://www.hindawi.com
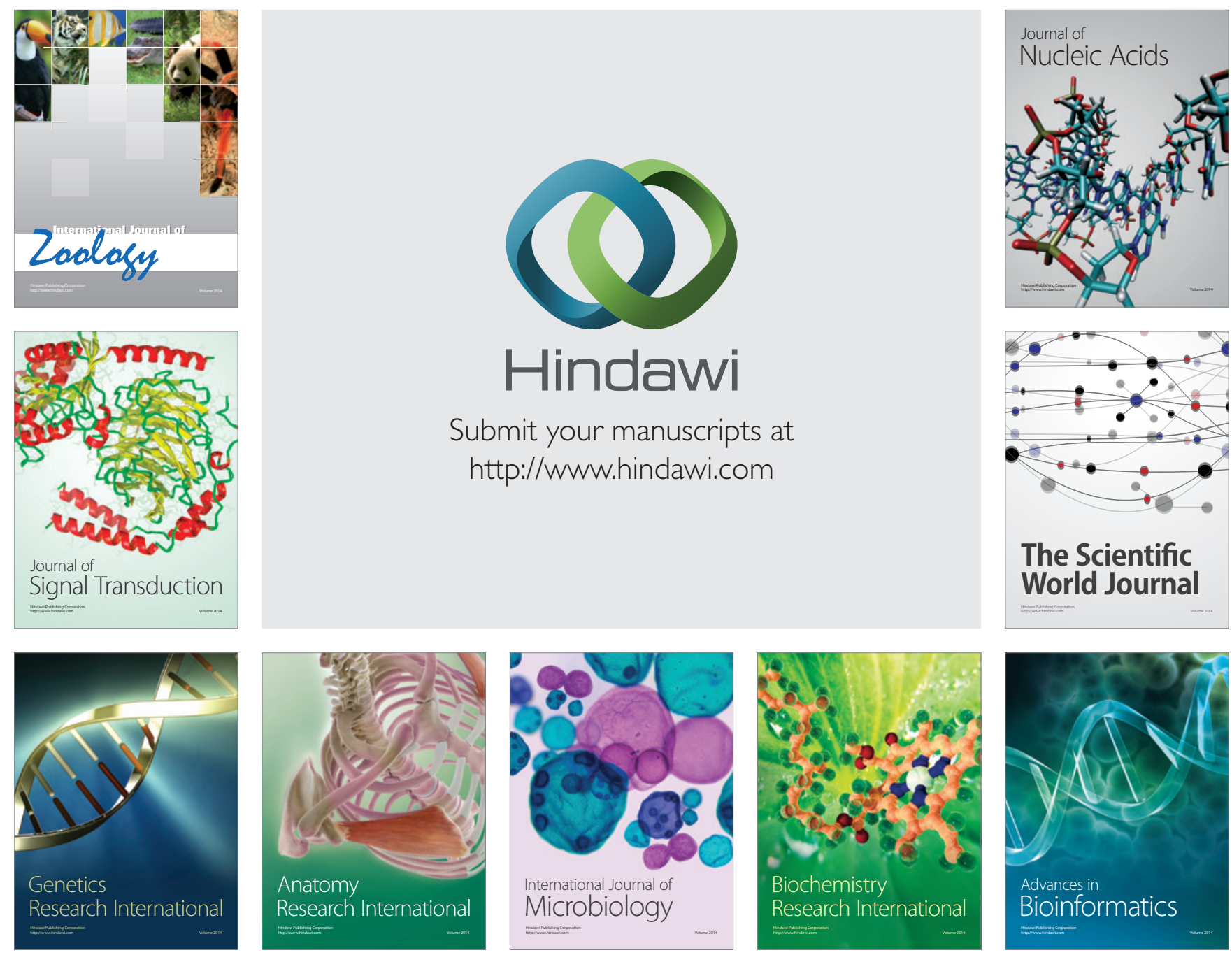

The Scientific World Journal
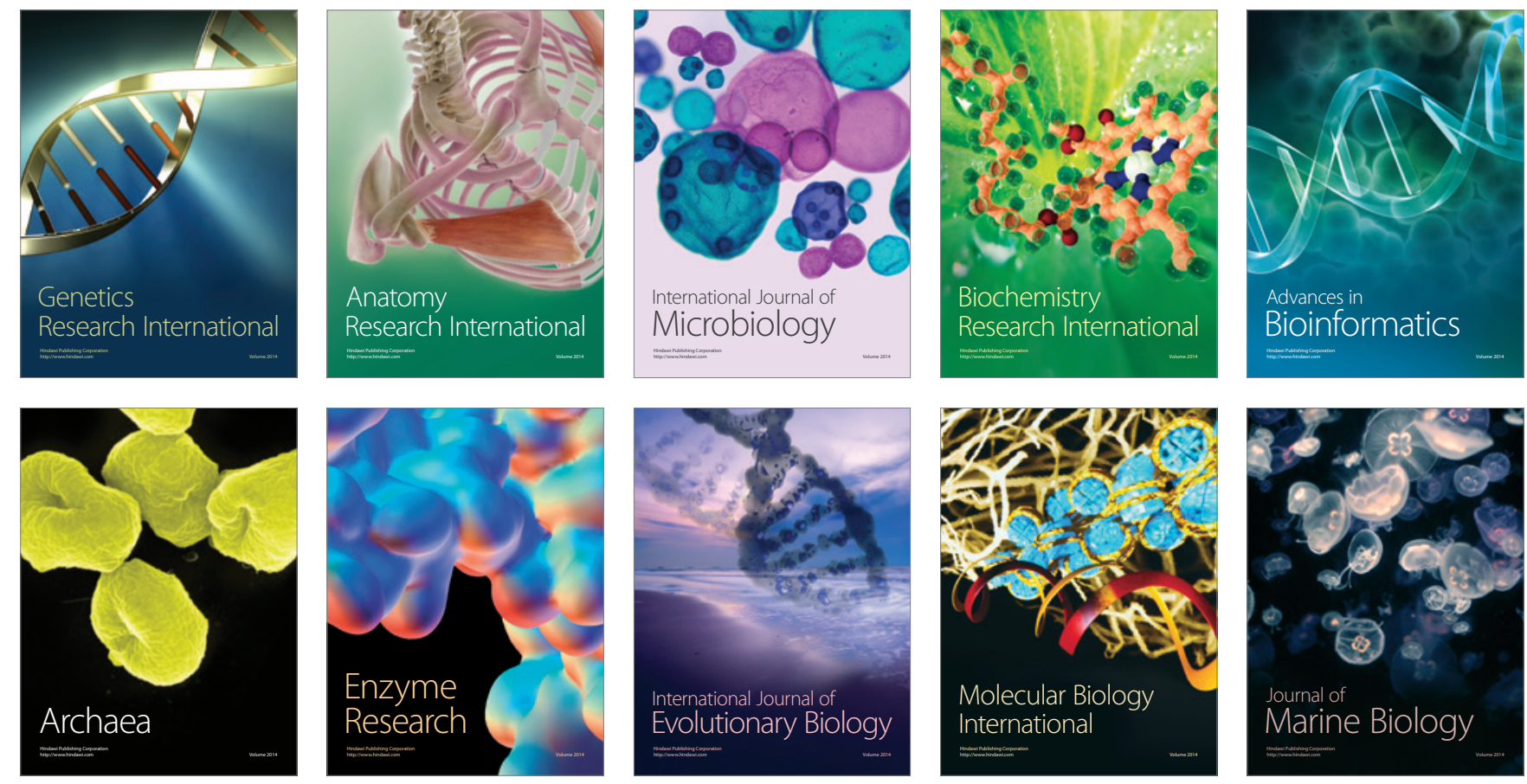